\title{
Pathogenicity of Lernaeocera lusci and L. branchialis in bib and whiting in the North Sea
}

\author{
P. A. van Damme ${ }^{1}$, F. Ollevier ${ }^{1}$, O. Hamerlynck ${ }^{2}$ \\ ${ }^{1}$ Laboratory for Ecology, Zoological Institute, Naamsestraat 59, B-3000 Leuven, Belgium \\ ${ }^{2}$ Section Marine Biology, Ledeganckstraat 35, B-9000 Gent, Belgium
}

\begin{abstract}
The pathogenicity of the crustacean parasites Lernaeocera lusci and L. branchialis towards their definitive host species (bib and whiting, respectively) was studied in the Dutch and Belgian coastal area. Negative correlations between parasite intensity and haematocrit value were found for both parasite species. L. branchialis was the more pathogenic species: the parasite-induced reductions in haematocrit value were most significant for this species. It is assumed that parasite-induced host mortality can act as a regulatory force at high parasite densities in natural populations.
\end{abstract}

KEY WORDS: Lernaeocera Pathogenicity - Merlangius - Trisopterus - North Sea

\section{INTRODUCTION}

Lernaeocera lusci Bassett-Smith and L. branchialis L are copepod crustaceans with a heteroxenic life cycle. The intermediate host usually is a flatfish species whereas the definitive host usually is a gadoid species Their rather broad host specificity enables the parasites to infect different host species in different areas (Boxshall 1974, Kabata 1979, Tirard 1991, Van Damme 1993). In the southern North Sea (0+) bib Trisopterus luscus L. and (0+) whiting Merlangius merlangus L. are the typical definitive host species of $L$. lusci and $L$. branchialis, respectively (Sproston \& Hartley 1941, Potter et al. 1988, Van Damme 1993)

The effect of a number of marine parasites on the fitness of individual hosts is well documented (Kinne 1985). The impact of parasite-induced reductions in host fitness on the size and structure of host populations however is largely unknown. Though we know from ecological theory that parasite-induced host mortality can regulate parasite and host density (Anderson \& May 1978, May \& Anderson 1978) empiric evidence of this has hardly been given (Scott \& Dobson 1989).

The effect of the pennellid parasite Lernaeocera branchialis on its individual hosts, cod Gadus morhua L., haddock Melanogrammus aeglefinus L. or whiting, is well documented: it causes anaemia (Guillaume et al. 1983), affects the growth rate (Khan \& Lee 1989), reduces the swimming speed ( $\mathrm{H}$. Möller pers. comm.) and lowers energy reserves (Mann 1959, Van den Broek 1978, Müller 1983, Khan \& Lee 1989). In aquarium conditions infected fish have a lower survival rate than parasite-free fish (Khan et al. 1990). Khan (1988) assumed that $L$. branchialis can seriously affect the size and structure of natural host populations, but detailed quantitative studies are lacking.

Lernaeocera lusci appears to be less pathogenic towards bib, but this may reflect the lower number of studies dealing with the biology of this species (Evans et al. 1983, Eiras 1986). The aim of this study is to compare the pathogenicity of L. lusci and L. branchialis towards their definitive hosts. We will particularly study the additive effect of different parasite intensities on the host haematocrit value

\section{MATERIAL AND METHODS}

Fish were sampled during 2 coastal surveys. On 2 October $1991 \mathrm{bib}$ and whiting were collected from a research vessel in the Belgian coastal area. The mean $( \pm S D)$ total lengths of the $(0+)$ bib and $(0+)$ whiting examined were $163 \pm 18$ and $200 \pm 22 \mathrm{~mm}$, respectively. On 21 October 1991 samples were collected from a 
commercial shrimp trawler in the Oosterschelde (Roompot). The mean total lengths of bib and whiting examined were $169 \pm 17$ and $209 \pm 21 \mathrm{~mm}$.

Immediately after capture, the haematocrit value of blood sampled from the vena caudalis was determined. Heparinised microhaematocrit tubes were filled with blood, one end was sealed and samples were then centrifuged in a micro-haematocrit centrifuge for $3 \mathrm{~min}$. The haematocrit value was calculated as the ratio of erythrocytes to plasma. After blood sampling, the fish were labelled and preserved in $8 \%$ formalin. The numbers of Lernaeocera lusci and L. branchialis were counted in the laboratory. Only fish with mature parasites ( $\mathrm{X}$ substages according to the nomenclature of Van Damme \& Hamerlynck 1992) and carrying no dead parasites ( $Z$ substagc) worc included in the analysis. Fish carrying only dead parasites were attributed to a separate infection class.

The haematocrit values were examined by regression analyses. The regression equations describing the relationship between haematocrit value $(H)$ and the number of parasites $\left(x_{1}\right)$ and the length of the fish $\left(x_{2}\right)$ were calculated according to

$$
H=a+b_{1} x_{1}+b_{2} x_{2}
$$

where $a=$ intercept and $b_{1}, b_{2}=$ regression coefficients

\section{RESULTS}

\section{Belgian coastal area}

The mean total lengths of the fish in the infection classes were not significantly different (ANOVA, $p>0.05$ ) (Table 1). The relationship between the number of parasites and the haematocrit level of the re-

Table 1 Mean fish length $(T L, \pm S D$ ) and haematocrit value $\left(H_{i} \pm \mathrm{SD}\right)$ of bib Trisopterus luscus and whiting Merlangius merlangus with 0, 1, 2, $>2$ or Z parasites (Lernaeocera lusci and L. branchialis, respecitvely) in the Belgian coastal area

\begin{tabular}{|c|c|c|c|c|}
\hline & $n$ & $\begin{array}{c}\mathrm{TL} \\
(\mathrm{mm})\end{array}$ & $H$ & $\% H$ \\
\hline \multicolumn{5}{|c|}{ Trisopterus luscus } \\
\hline 0 & 31 & $167 \pm 21$ & $41 \pm 5$ & 100 \\
\hline 1 & 15 & $157 \pm 17$ & $40 \pm 8$ & 98 \\
\hline 2 & 3 & 167 & 36 & 87 \\
\hline$>2$ & 2 & 152 & 30 & 71 \\
\hline \multicolumn{5}{|c|}{ Merlangius merlangus } \\
\hline 0 & 20 & $193 \pm 12$ & $36 \pm 4$ & 100 \\
\hline 1 & 9 & $204 \pm 19$ & $29 \pm 5$ & 79 \\
\hline 2 & 4 & 221 & 23 & 62 \\
\hline Z & 6 & $214 \pm 31$ & $33 \pm 8$ & 91 \\
\hline
\end{tabular}

spective hosts in the North Sea is shown in Fig. 1. The linear regression equations fitted through the haematocrit values were highly significant $(p<0.05$ for both species). Infection of bib with 1,2 or 3 Lernaeocera Iusci resulted in a reduction in haematrocrit level of 2 , 13 and $29 \%$, respectively. In Table 1 it is shown that the presence of a $Z$ stage of $L$. branchialis resulted in a decrease in haematocrit level of $9 \%$.

The multiple regression equations describing the relationships between haematocrit value and both total fish length and number of parasites are shown in Table 2 . It can be seen that the haematocrit value was significantly affected by the number of parasites for both whiting $\left(b_{1}=-11.8\right)$ and bib $\left(b_{1}=-1.8\right)$. Only in bib was the haematocrit value also significantly correlated to fish length $\left(b_{2}-0.1\right)$.

\section{Oosterschelde}

There was a similar decrease in haematocrit value of both bib and whiting with increasing infection levels of
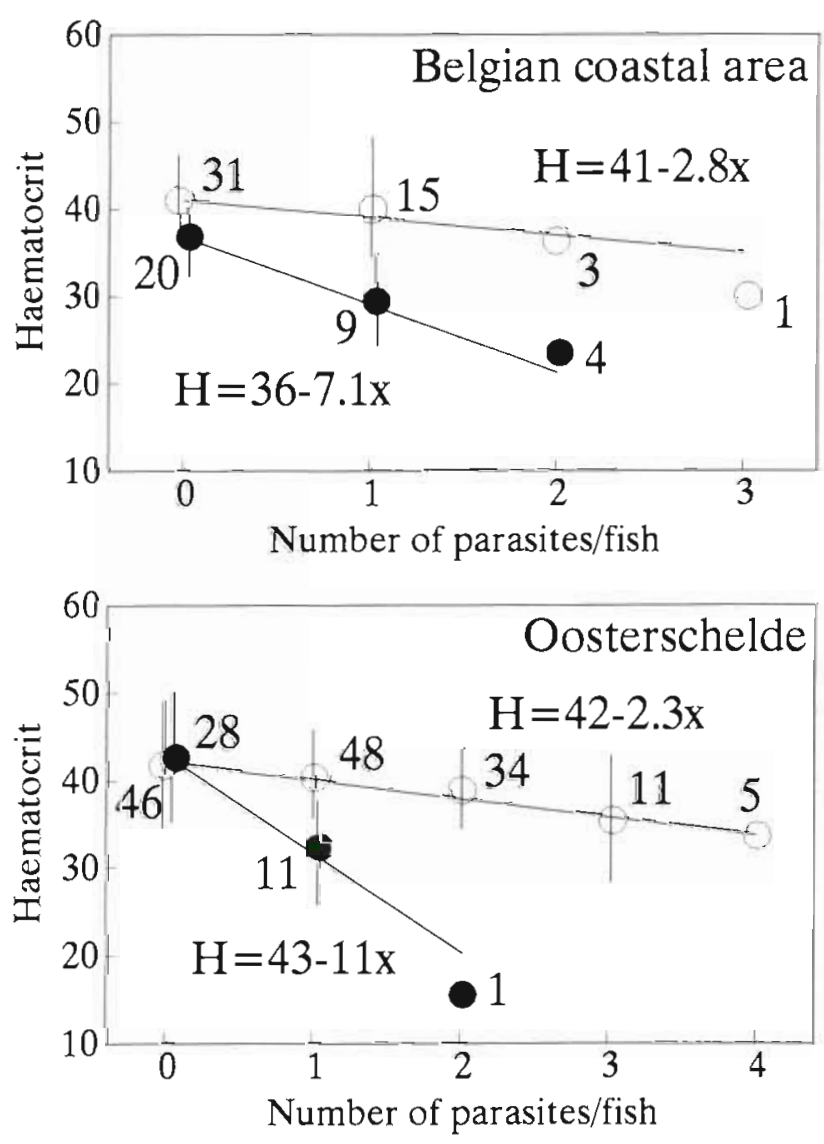

Fig. 1 Decrease in haematocrit values $(H)$ of whiting $(\bullet)$ and bib (O) due to infection ( $x=$ number of parasites host ${ }^{-1}$ ) with Lernaeocera branchialis and $L$. lusci, respectively, in the Belgian coastal area and in the Oosterschelde 
Table 2. Multiple regression equations describing the relationship between haematocrit $(H)$, number of Lernaeocera spp. $\left(x_{1}\right)$ and fish length $\left(x_{2}\right)$, according to $y=a+b_{1} x_{1}+b_{2} x_{2}$ (see text) for whiting and bib in the Belgian coastal area and in the Oosterschelde. ns: not significant $(p>0.05), \cdot p<0.05$; $\cdots p<0.01 ; \cdots p<0.001$

\begin{tabular}{|c|c|c|c|c|}
\hline & $\mathrm{n}$ & $a$ & $b_{1}$ & $b_{2}$ \\
\hline \multicolumn{5}{|c|}{ Belgian coastal area } \\
\hline Bib & 39 & 16.8 & $-1.8 *$ & $0.1^{*}$ \\
\hline Whiting & 40 & 42.2 & $-11.8 \cdots$ & $0.0 \mathrm{~ns}$ \\
\hline \multicolumn{5}{|c|}{ Oosterschelde } \\
\hline Bib & 151 & 31.9 & $-2.4^{\bullet}$ & $0.1^{\circ}$ \\
\hline Whiting & 33 & 26.7 & $-7.7^{\cdots} \cdots$ & $0.0 \mathrm{~ns}$ \\
\hline
\end{tabular}

Lernaeocera lusci and $L$. branchialis, respectively (Fig. 1). Infection with $L$. lusci and $L$. branchialis had a stronger effect on the haematocrit value of whiting (25\% and $65 \%$ reduction after infection with 1 and 2 parasites, respectively) than of bib (6\% and $11 \%$ reduction, respectively). The $\mathrm{Z}$ substages caused a decrease of $15 \%$ in whiting (Table 3 ).

Table 3. Mean fish length ( $\mathrm{TL}, \pm \mathrm{SD}$ ) and haematocrit value $(H, \pm \mathrm{SD})$ of bib Trisopterus luscus and whiting Merlangius merlangus with $0,1,2,>2$ or Z parasites (Lernaeocera lusci and $L$. branchialis, respectively) in the Oosterschelde

\begin{tabular}{|ccccr|}
\hline & $\mathrm{n}$ & $\begin{array}{c}\mathrm{TL} \\
(\mathrm{mm})\end{array}$ & $H$ & $\% H$ \\
\cline { 1 - 2 } & & & & \\
\hline Trisopterus luscus & & & & \\
0 & 46 & $166 \pm 15$ & $42 \pm 7$ & 100 \\
1 & 48 & $177 \pm 14$ & $40 \pm 6$ & 94 \\
2 & 34 & $174 \pm 20$ & $38 \pm 5$ & 89 \\
3 & 11 & $176 \pm 14$ & $36 \pm 6$ & 85 \\
4 & 5 & 161 & 33 & 77 \\
Merlangius merlangus & & & \\
0 & 28 & $207 \pm 17$ & $43 \pm 9$ & 100 \\
1 & 11 & $212 \pm 29$ & $32 \pm 6$ & 75 \\
2 & 1 & 220 & 15 & 35 \\
$\mathrm{Z}$ & 8 & $204 \pm 23$ & $36 \pm 10$ & 85 \\
\hline
\end{tabular}

The multiple regression equations are shown in Table 2. As observed for the Belgian coast there was an effect of bib length on the haematocrit value $\left(b_{2}=0.1\right)$. The effect of parasitic infection on the haematocrit value was significant for both species $(p<0.05)$. It was stronger in whiting $\left(b_{1}=-7.7\right)$ than in bib $\left(b_{1}=-2.4\right)$.

\section{DISCUSSION}

A wide range of factors may influence the abundance of copepod parasites on either intermediate or definitive hosts. Recently, interest has focused on the role of density-dependent factors because of their po- tential to regulate parasite populations (Scott \& Dobson 1989). However, it can be assumed that density-dependent factors are of little importance in determining the infection level of Lernaeocera species in the intermediate hosts. Intraspecific competition for resources, the effect of host immune responses, and parasite-induced host mortality probably do not constrain the number of larval stages in the flatfish hosts: it was indeed found by several authors that the number of parasites per intermediate host individual can accumulate to seemingly unconstrained numbers $(630 \mathrm{~L}$. lusci on 1 sole, 630 L. branchialis on 1 flounder, 580 L. branchialis on 1 lemon sole, 26700 L. branchialis on 1 lumpfish; (Kabata 1958, Templeman et al. 1976, Van Damme 1993).

At least one density-dependent factor may partly determine the abundance of parasites on the definitive host: whereas the role of host immunity and intraspecific competition is considered to be negligible (Van Damme 1993), the probability of survival of the definitive host (and hence of the parasite) may be affected by the presence of the parasite. It was found in the present study that Lernaeocera branchialis is more pathogenic towards its definitive hosts than L. lusci: the reduction in haematocrit is more significant in the former species than in the latter species. The differences in pathogenicity between the 2 species are also reflected in the literature on this subject. Mann (1953), Kabata (1958) and Khan \& Lee (1989) all recorded significant effects of $L$. branchialis on the condition of its host, whereas Evans et al. (1983) and Eiras (1986) failed to find evidence for pathogenic effects of $L$. lusci.

It has been suggested by several authors that the decrease in haematocrit value is an indication for a lower metabolic rate, which in its turn may result in reduced swimming speed, increased susceptibility to predators and lower efficiency in prey uptake (Blaxhall 1972, Hille 1982, Boon et al. 1990). Pathogenic parasites such as Lernaeocera branchialis, which induce a decrease in haematocrit value of their host, may significantly affect host fitness. As a consequence, infected fish may suffer from higher mortality rates than parasite-free fish. Hence the assumption that heavily infected fish may be eliminated from the population, which may result in a decrease in overall parasite abundance. This hypothesis, that present-day regulation of parasite abundance may occur through the action of parasiteinduced host mortality, cannot be tested in field studies. There are only some scarce indications that the higher pathogenicity of $L$. branchialis (in comparison with $L$. lusci) is negatively correlated with the overall abundance of the species. In the Dutch Delta the abundance of $L$. branchialis is generally lower than the abundance of $L$. lusci, and fish with more than 2 parasites of the former species are rarely found in the area 
(Van Damme 1993). However, these lower abundances found for $L$. branchialis may result from a wide range of environmental factors influencing the transmission success of this parasite species in the study area. Indeed, some authors (Sproston \& Hartley 1941, Mann 1953, Van den Broek 1978) found that infection levels of $L$. branchialis can be higher in other areas.

At first sight it appears that high pathogenicity is an evolutionarily unstable strategy: the virulent parasite dies together with the host which is killed. This view of host-parasite associations expresses the conventional wisdom that parasites evolve to be harmless to their hosts: a view which, although often operating as a paradigm, was criticised by Toft \& Aeschlimann (1991) as being overly simplistic. The theoretical models of Anderson \& May (1978) and May \& Anderson (1978) indeed attributed a central role to pathogenicity in stabilising the host-parasite interaction. Application of their theoretical considerations to the whitingLernaeocera association and to the bib-Lemaeocera association is largely speculative. If parasite-induced host mortality acts as a regulatory force, then parasite intensity may be in equilibrium and may fluctuate around levels which can be supported by the host population. Let us turn to $L$. branchialis on whiting: the reason for this parasite species' virulence is presumably its penetration of the heart of its host (Mann 1953, Kabata 1981, Khan 1988). The heart may provide a better food source than blood vessels and this may affect the reproductive rate of this parasite. Thus, the reduction in parasite population size (due to parasiteinduced host mortality) may be compensated for by increased reproductive output per individual parasite. Moreover, infection of the heart may result in parasiteinduced changes in host behaviour resulting in increased transmission to the next host in the life cycle (Sproston \& Hartley 1941). L. lusci is obviously less pathogenic than $L$. branchialis. The reason for this lower pathogenicity is probably related to the site of attachment of this parasite species (gill arches). For this species parasite-induced host mortality may operate as a regulatory force at higher infection levels than for $L$. branchialis.

Acknowledgements. We are grateful to D. Maertens and N. Hoebeke for logistic support. This study was supported by FKFO project 2.0086.88. P.A.V.D. was supported by the National Science Foundation of Belgium (NFWO). The paper is contribution no. 641 of the Netherland Institute of Ecology, Centre for Estuarine and Coastal Ecology, The Netherlands.

\section{LITERATURE CITED}

Anderson, R. M., May, R. M. (1978). Regulation and stability of host-parasite population interactions. I. Regulatory processes. J. Anim. Ecol. 47: 219-247

Blaxhall, P. C. (1972). The haematological assessment of the health of freshwater fish: a review of selected literature. J. Fish Biol. 4: 593-604

Boon, J. H., Cannaerts, V. M. H., Augustijn, H., Machiels, M. A. M., De Charleroy, D., Ollevier, F. (1990). The effect of different infection levels with infective larvae of Anguillicola crassus on haematological parameters of European eel (Anguilla anguilla). Aquaculture 87: 243-253

Boxshall, G. A. (1974). Infections with parasitic copepods in North Sea marine fishes. J. mar. biol. Ass. U.K. 54 $355-372$

Eiras, J. C. (1986). Some aspects of the infection of bib Trisopterus luscus (L.) by the parasitic copepod Lernaeo cera lusci (Basset-Smith 1896) in Portuguese waters. J. Fish Biol. 28: 141-145

Evans, N. A., Whitfield, P. J., Bamber, R. N., Espin, P. M. (1983). Lernaeocera lusci (Copepoda: Pennellidae) on bib (Trisopterus luscus) from Southampton Water. Parasitology 86: $161-173$

Guillaume. C. Douëllou. L. Romestand. R. Trilles, I. P (1983). Influence d'un parasite hématophage: Lemaeocera branchialis (L., 1767) (Copépode, Pennellidae) sur les constantes erythrocytaires de son hôte Merluccius merluccius (L., 1758). Rev. Trav. Inst. Pêch. marit. 47: 55-61

Hille, S. (1982). A literature review of the blood chemistry of rainbow trout, Salmo gairdneri Rich. J. Fish Biol. 20: 535-569

Hislop, J. R. G., Shanks, A. M. (1979). Recent investigations on reproductive biology of the haddock Melanogrammus aeglefinus of the northern North Sea and the effects on fecundity of infection with the copepod parasite Lernaeocera branchialis. J. cons. int. Exp. Mer 39: 244-251

Kabata, Z. (1958). Lemaeocera obtusa n. sp.: its biology and its effects on the haddock. Mar. Res. Dep. Agric. Fish. Scotl. 3: 1-26

Kabata, Z. (1979). Parasitic Copepoda of British fishes. The Ray Society, London

Kabata, Z. (1981). Copepoda (Crustacea) parasitic on fishes: problems and perspectives. Adv. Parasitol. 19: 1-71

Khan, R. A. (1988). Experimental transmission, development and effects of a parasitic copepod, Lernaeocera branchialis on Atlantic cod, Gadus morhua. J. Parasitol. 74: 586-599

Khan, R. A., Lee, E. M. (1989). Influence of Lernaeocera branchialis (Crustacea: Copepoda) on growth rate of Atlantic cod Gadus morhua. J. Parasitol. 75: 449-454

Khan, R. A., Lee, E. M., Barker, D. (1990). Lernaeocera branchialis: a potential pathogen to cod ranching. J. Parasitol. 76: 913-917

Kinne, O. (ed.) (1985). Diseases of marine animals, Vol. IV, Pisces. Biologische Anstalt Helgoland, Hamburg

Mann, H. (1953). Lernaeocera branchialis (Copepoda, Parasitica) und seine Schadwirkung bei einigen Gadiden. Arch. FischWiss. 4: 133-143

May, R. M., Anderson, R. M. (1978). Regulation and stability of host-parasite population interactions. II. Destabilizing processes. J. Anim. Ecol. 47: 249-267

Müller, $H$. (1983). The effects of Lernaeocera-infestation on cod (Gadus morhua). Bull. Eur. Ass. Fish Path. 3: 21-22

Potter, I. C., Garder, D. C., Claridge, P. N. (1988). Age composition, growth, movements, meristics and parasites of the whiting, Merlangius merlangus, in the Severn Estuary and British Channel. J. mar. biol. Ass. U.K. 68: 295-313

Scott, M. E., Dobson, A. (1989). The role of parasites in regulating host abundance. Parasitology Today 5: 176-183

Sposton, N. G., Hartley, P. H. T (1941). The ecology of some parasitic copepods of gadoids and other fishes. J. mar. biol. Ass, U.K. 25:361-392 
Templeman, W., Hodder, V. M., Fleming, A. M. (1976). Infection of lumpfish (Cyclopterus lumpus) with larvae and of Atlantic cod (Gadus morhua) with adults of the copepod, Lernaeocera branchialis, in and adjacent to the Newfoundland area, and inferences therefrom on inshoreoffshore migrations of cod. J. Fish. Res. Bd Can. 33 $711-731$

Tirard, C. (1991). Biodiversité et biogéographie évolutive dans les systèmes hôtes-parasites: le modèle Gadiformes (Télèostéens) - Copépodes et Monogènes. Ph.D. thesis, Univ. Montpellier

Toft, C. A., Aeschlimann, A. (1991). Introduction: coexistence or conflict? In: Toft, C. A., Aeschlimann, A., Bolis, L. (eds.) Parasite-host associations: coexistence or conflict? Oxford University Press, Oxford, p. 1-11

Van Damme, P. A. (1993). The suprapopulation dynamics

Responsible Subject Editor: W. Körting, Hannover, Germany of the marine fish parasites Lernaeocera lusci and L. branchialis (Copepoda, Pennellidae). Ph.D. thesis, Univ. Leuven

Van Damme, P. A., Hamerlynck, O. (1992). The infection dynamics and dispersion pattern of Lernaeocera branchialis L. on $0+$ whiting (Merlangius merlangus L.) in the Oosterschelde (SW Netherlands). J. Fish Biol. 41: 265-275

Van den Broek, W. L. F. (1978). The effects of Lernaeocera branchialis on the Merlangius merlangus population in the Medway estuary. J. Fish Biol. 13: 709-715

Whitfield, P. J., Pilcher, M. W., Grant, H. J., Riley, J. (1988). Experimental studies on the development of Lernaeocera branchialis (Copepoda: Pennellidae): population processes from egg production to maturation on the flatfish host. Hydrobiologia 167/168: 579-586

Manuscript first received: October 4, 1993

Revised version accepted: December 20, 1993 